\title{
Spor Hizmeti Alan Bireylerin Sosyal Görünüş Kaygısı ve Öznel Mutluluklarının İncelenmesi ${ }^{1}$
}

\author{
Ali Gürel GÖKSEL ${ }^{2} \quad$ Çağdaş CAZ $^{3} \quad$ Ömer Faruk YAZICl ${ }^{4} \quad$ Ercan ZORBA $^{2}$
}

\author{
${ }^{2}$ Muğla Sıtkı Koçman Üniversitesi, Spor Bilimleri Fakültesi, MUĞLA \\ ${ }^{3}$ Yozgat Bozok Üniversitesi, Beden Eğitimi ve Spor Yüksekokulu, YOZGAT \\ ${ }^{4}$ Tokat Gaziosmanpaşa Üniversitesi, Erbaa Meslek Yüksekokulu, TOKAT
}

Künye: Göksel, A.G., Caz, Ç., Yazıcı, Ö.F. ve Zorba, E. (2018). Spor Hizmeti Alan Bireylerin Sosyal Görünüş Kaygısı ve Öznel Mutluluklarının İncelenmesi. Gaziantep Üniversitesi Spor Bilimleri Dergisi, 3(3): 88-101.

\section{Öz}

Çalışmanın amacı; spor hizmeti alan bireylerde sosyal görünüş kayısı ile öznel mutluluk ilişkisini açıklamaktır. Çalışma grubunu; İstanbul ilinde yer alan spor merkezlerine gelen ve tesadüfi yöntemle çalışmaya dâhil edilen 238 (146 kadın, 92 erkek) birey oluşturmuştur. Araştırmada veri toplama aracı olarak; Hart ve arkadaşları (2008) tarafından geliştirilen, Doğan (2010) tarafından Türkçe'ye uyarlanan ve geçerlik-güvenirlik çalışması yapılan "Sosyal Görünüş Kaygısı Ölçeği” ile Lyubomirsky ve Lepper (1999) tarafından geliştirilen ve Akın ve Satıcı (2011) tarafından Türkçe'ye uyarlanan "Öznel Mutluluk Ölçeği" kullanılmıştır. Verilerin değerlendirilmesinde istatistiksel yöntem olarak; betimsel istatistik, bağımsız gruplar için t-testi, tek yönlü varyans analizi (Anova), Tukey çoklu karşılaştırma testi ve bağımlı değişkenler arasındaki ilişkiyi belirlemek için Pearson Correlation testi kullanılmıştır. Araştırma sonucunda; katılımcıların mutluluk düzeyleri gelir durumu değişkenine göre anlamlı farklılık gösterirken, gelir durumlarının sosyal görünüş kaygısında etkili olmadığı tespit edilmiştir. Ayrıca, mutluluk ile sosyal görünüş kaygısı arasında negatif yönde düşük düzeyde ilişki olduğu tespit edilmiştir.

\section{Orijinal Makale}

\section{Yayın Bilgileri}

Gönderi Tarihi: 15.06.2018

Kabul Tarihi: 13.09 .2018

Yayın Tarihi: 24.09.2018

\section{Sorumlu Yazar}

e-mail: cazcagdas@gmail.com

DOI: $10.31680 /$ gaunjss.434184

Anahtar Kelimeler: Sosyal Görünüş, Kaygı, Öznel Mutluluk, Spor Hizmeti

\section{Investigation of Individuals Who Use Sports Service' Social Appearance Anxiety and Subjective Happiness}

\begin{abstract}
The aim of the research was to explain the relationship between social appearance anxiety of taking sport service of individuals and their subjective happiness. The sample of study consists of 146 female and 92 male, a total of 238 individuals who receive services from a private sports center in the province Istanbul. In this research, "Social Appearance Anxiety Scale" that was developed firstly by Hart et al. (2008) and adapted to Turkish by Dogan (2010) together with "Subjective Happiness Scale" that was developed by Lyubomirsky and Lepper (1999) and adapted to Turkish by Akin and Satici (2011) and were used to collect data. In the evaluation of data as statistical analyses; descriptive statistics, for independent groups t-test, one way analysis of variance (ANOVA), Tukey's multiple comparison test and Pearson Correlation test was used to determine the relationship between the dependent variables. As a result of the research; participants' happiness levels showed significant differences according to income status variables, there were no significant differences for social appearance anxiety. Additionally a negative low level significant relationship was found between happiness and social appearance anxiety.
\end{abstract}

Key Words: Social Appearance, Anxiety, Subjective Happiness, Sports Service

\section{OriginalArticle}

Article Info

Received: 15.06 .2018

Accepted: 13.09 .2018

Published: 24.09.2018

\section{Corresponding Author}

e-mail: cazcagdas@gmail.com

\footnotetext{
${ }^{1} \mathrm{Bu}$ çalışmanın özeti, 01-04 Kasım 2016 tarihinde Antalya'da düzenlenen 14. Uluslararası Spor Bilimleri Kongresi'nde poster olarak sunulmuştur.
} 


\section{Giriş}

Fiziksel görünüm, tarih boyunca insanların yaşamında önem arz etmiştir (Yazıcı, Caz ve Tunçkol, 2016a). Tarih boyunca ve günümüzde ince, sağlıklı, kaslı vb. özelliklere sahip olmak ve başkaları üzerinde olumlu izlenim bırakmak bireyler için önemli olmuştur. İnsanlar güzel olmayı, olumlu, çirkin olmayı da olumsuz değerlerle şekillendirmektedirler. Bu durumu kitle iletişim araçları da desteklemekte, sunulan ideal beden tasarımları bireylerin duygu ve düşüncelerini değiştirmekte, beden algılarını etkilemektedir (Yaman, Koşu, Tel, Teşneli, Yalvaracı ve Gelen, 2008; Yaşartürk, Çalık, Kul, Türkmen, ve Akyüz, 2014). Günümüzde her yaşta insanın özelikle de genç neslin önemle üzerinde durduğu konulardan biri fiziksel görünüş olmuştur. Sosyal kaygı, insanların sosyal yada performans korkusundan özellikle tanımadığı yada bilmediği kişilerle yada diğer insanlar tarafından değerlendirme durumlarında ortaya çıkmaktadır (Gautreau, Simon, Mushqash ve Sherry, 2015).

Sosyal görünüşü etkileyen fiziksel zayıflığın ya da yakışıklılığın kültürel bir değer olarak yansıtıldığı reklam, magazin ve TV programlarında fiziksel görünüş, gündelik hayatta çoğu zaman bireyin düşünce, duygu, davranış ve başarılarının önüne geçebilmektedir (Çepikkurt ve Coşkun, 2010). İnsanların çoğu çekici bireylerle daha fazla iletişim kurmak istemektedirler (Alemdağ ve Öncü, 2015). Bundan dolayı bireyler diğer insanlar üzerinde daha etkili bir izlenim bırakmak ve çekici görünmek için çabalamaktadırlar (Yousefi ve ark., 2009). Bu yüzden insan, diğer insanlar üzerinde daha çekici ve olumlu bir izlenim bırakmak için harekete geçerler. Olumlu bir izlenim bırakamayacaklarını düşündüklerinde ise bireyler kaygı yaşarlar (Leary ve Kowalski, 1995). Oluşan bu kaygı, sosyal görünüş kaygı olarak adlandırılmaktadır (Kara, 2016). Bu düşünceyle sosyal görünüş kaygısı, insanların, başkaları tarafından kendi fiziksel görüntülerinin değerlendirilmesine karşı hissettikleri duygusal tepkidir (Çınar ve Keskin, 2015). Benzer bir ifade ile sosyal görünüş kaygısı kavramı, bireyin fiziksel görünüşü ile ilgili algılamalarını, tutum ve davranışlarını ve geçmişten bugüne uzanan deneyimlerini kapsayan bir kavramdır (Cash ve Fleming, 2002).

Sosyal bir varlık olan insanoğlunun hayatlarını idame ettikleri toplumsal çevrede, gün geçtikçe daha karmaşık bir duruma gelmekte ve kişiler bakımından çözümlenmesi zor bir durum almaktadır. Yaradılış olarak karışıklık ve belirsizlikte haz almayan, aşırı stres ve kaygı ile yüz yüze gelen insanlar "mutsuz insan kitleleri" giderek mutluluk kavramına daha fazla önem vermeye başlamışlardır (Yazıcı, Caz ve Tunçkol, 2016b). Araştırmacıların uzun yıllardır üzerinde çalıştıkları bir konu olan 
mutluluk olgusu, günümüzde çeşitli koşulların ortaya çıkardığı olumsuz etkiler sonucunda çok daha fazla araştırılmaya intiyaç duyulan bir kavram haline gelmiştir (Baysal ve Aka, 2013). Mutluluğun bireyi olumlu yönde etkilediği konusunda görüş birliği sağlanmış olsa da; ne olduğu, bireylerin nasıl mutlu olduğu konusunda birlik sağlanamamıştır (Akın ve Satıcı, 2011). Bireylerin mutluluğuna neden olan etkenlerin araştırıldığı çalışmalar sonucunda; yaşam doyumu (Deci ve Ryan, 2000; Elliot ve diğ,, 1997), yaşam olayları (Costa ve McCrae, 1980; Headey ve Wearing, 1989), kaygı (Deci ve ark.,, 2001; Kasser ve Ryan, 1999), başarılar (Emmons, 1986; Omodei ve Wearing, 1990) ve uyum düzeyi (Michalos, 1985), mutluluğun önemli belirleyicileri olarak nesnel bir bakış açısı sunmuştur ancak son çalışmalar göstermiştir ki; nesnel yaklaşımlar mutluluğu tam olarak açıklayamamaktadır. Bu sebepten dolayı araştırmacılar öznel yapıları araştırmaya yönelmiştir.

Mevcut çalışmada da öznel mutluluk kavramı sosyal görünüş kaygısı ile açıklanmaya çalışılmıştır. Birçok araştırmanın sonucu, sosyal görünüş ve öznel mutluluk arasındaki ilişkiye dikkat çekmektedir. Diener ve ark., (1995) fiziksel çekicilik ve öznel mutluluk arasındaki ilişkiye dikkat çekmiştir. Donaghue (2009), beden imajı ve öznel mutluluk ilişkisini araştırdığı çalışmasında, fiziksel memnuniyet ile mutluluk arasında anlamlı bir ilişkinin varlığını tespit etmiştir. Farklı bir araştırmalarda ise özellikle kadınların fiziksel görünümlerinden memnun olmaları halinde tüm yaşamlarından memnun oldukları ve mutluluklarının bir belirleyicisi olduğunu gösteren bulgular mevcuttur (Katz ve Farrow, 2000; Tiggeman, 1994). Yine Durkin ve Paxton (2002), adölesan dönemindeki bireylerle gerçekleştirdiği çalışmasında sosyal görünüş ve mutluluk arasındaki ilişkiye dikkat çekmiştir. Farklı sınıf seviyelerindeki ergenlerle yaptıkları çalışmada beden imajı ve öznel iyi oluş arasındaki ilişkiye dikkat çekmiştir. Tuzgöl (2006)'de, üniversite öğrencilerinin dâhil olduğu çalışmasında fiziksel görünüşten memnuniyet ile mutluluk arasında anlamlı bir ilişki olduğunu saptamıştır.

Sosyal görünüş ve mutluluğa ilişkin elde edilen bilgiler ışığında, bu kavramların insanlar açısından son derece önemli olduğu algılanmaktadır. Bireyler için son derece önemli olan sosyal görünüş ve mutluluk kavramı, spor hizmeti satın alan bireylerin mutluluk ve sosyal görünüş düzeylerinin ortaya konulması, sosyal görünüş ve mutluluk arasındaki ilişkinin incelenmesi ve bireylerin mutluluğunu etkileyen, sosyal görünüşlerine etki eden değişkenlerin belirlenmesi noktasında da önem kazanmaktadır. Bu düşüncelerden hareketle çalışmanın amacını; spor hizmeti 
alan bireylerde sosyal görünüş kayısı ile öznel mutluluk arasındaki ilişkinin açıklanması oluşturmaktadır. Belirtilen amaç ve bilgiler ışığında şu sorulara cevap aranmıştır;

(1) Araştırma dâhilinde sosyal görünüş kaygısı ve öznel mutluluk puan dağılımı nasıldır?

(2) Cinsiyet değişkenine göre bireylerin sosyal görünüş kaygıları ve mutluluk düzeylerinde anlamlı farklılık var mıdır?

(3) Bireylerin yaş değişkenine göre sosyal görünüş kaygıları ve mutluluk düzeylerinde istatistiksel olarak anlamlı farklılık var mıdır?

(4) Bireyler medeni durum değişkenine göre sosyal görünüş kaygıları ve mutluluk düzeylerinde istatistiksel olarak anlamlı farklılık var mıdır?

(5) Bireylerin gelir durumu değişkenine göre sosyal görünüş kaygıları ve mutluluk düzeylerinde istatistiksel olarak anlamlı farklılık var mıdır?

(6) Bireylerin sosyal görünüş kaygıları ve öznel mutluluk düzeyleri arasında anlamlı bir ilişki var mıdır?

\section{Yöntem}

Araştırmanın bu bölümünde çalışmanın örneklem grubu, araştırmada kullanılan veri toplama araçları, verilerin toplanması hakkında açıklayıcı bilgiler ile toplanan verilerin analizleriyle ilgili detaylı bilgi verilmektedir.

\section{Araştırma Grubu}

Araştırmanın çalışma grubunu, İstanbul ilinde yer alan spor merkezlerine gelen ve tesadüfi yöntemle çalışmaya dâhil edilen 238 kişi (146 kadın, 92 erkek) birey oluşturmuştur.

\section{Veri Toplama Araçları}

Mevcut araştırmada veri toplama aracı olarak, "Sosyal Görünüş Kaygısı Ölçeği”, "Öznel Mutluluk Ölçeği” ve araştırmacılar tarafından oluşturulan kişisel bilgi formu kullanılmıştır. Hart ve ark., (2008) tarafından geliştirilen ve Doğan (2010) tarafından Türkçe'ye uyarlanan "Sosyal Görünüş Kaygısı Ölçeği” toplam 16 maddeden oluşmakta ve 5'li likert tipinde (Çok sık:5, Sıkça:4, Bazen:3, Neredeyse hiç:2 ve Hiç:1) puanlanmaktadır. Ölçek tek boyutlu olup, 1. maddesi olumsuz olduğundan ters kodlanarak işleme tabi tutulmuştur. Hart ve ark., (2008) "Ölçekten 
alınan puanların ortalaması yükseldikçe kaygı düzeyinin arttığını, ortalama düştükçe kaygı düzeyi düştüğünü ifade etmişlerdir". Araştırma kapsamında ölçeğin Cronbach Alpha iç tutarlılık katsayısı $\alpha=, 926$ olarak hesaplanmıştır.

Lyubomirsky ve Lepper (1999) tarafından geliştirilen ve Akın ve Satıcı (2011) tarafından Türkçe'ye uyarlanan "Öznel Mutluluk Ölçeği" 4 madde ve 7'li likert tipi derecelendirmeden oluşmaktadır. Ölçek tek boyutlu olup, 4. maddesi olumsuz ifade içerdiğinden analiz yapılmadan önce ters kodlanmıştır. Araştırma kapsamında ölçeğin Cronbach Alpha iç tutarlılık katsayısı $\alpha=, 556$ olarak hesaplanmıştır.

\section{Verilerin Toplanması}

Veri toplama işlemi, gün içerisinde özel bir spor merkezinin çeşitli şubelerinde spor hizmeti almak için gelen bireyler üzerinde gerçekleştirilmiştir. Bireylerin daha gerçekçi, sabırlı ve doğru cevap verebilmeleri için spor yapmaya başlamadan önce anketleri doldurmaları istenmiştir. Çalışmada gönüllü katılım ilkesine bağı kalınmış ve gerekli bilgi verildikten sonra dağıtılan anket formları dağıtılmıştır. Toplanan anket formlarından eksik/hatalı olanlar çıkarıldıktan sonra geriye kalan 238 adet anket formu bilgisayar ortamına aktarılmıştır.

\section{Verilerin Analizi}

Araştırma kapsamında toplanan veriler; betimsel istatistik, bağımsız iki grup için T-testi, Anova ile korelasyon analizine tabi tutulmuştur. Anlamlı farkın hangi gruplar arasında olduğunu tespit edebilmek için Tukey HSD değerlerine bakılmıştır. Ölçeğin güvenirliği, Cronbach Alpha iç tutarlık katsayıları hesaplanarak belirlenmiştir. Verilerin normallik varsayımını sağlayıp sağlamadığı çarpıklık ve basıklık testi ile ölçülmüştür. Analiz sonucu çıkan değerlerin normallik varsayımını sağladığı, bu nedenle de parametrik testlerin uygulanmasının uygun olduğuna karar verilmiştir.

\section{Bulgular}

Çalışmanın bu bölümünde araştırma sonucunda elde edilen bulgular yer almaktadır. Bulgular, tablolar ve tablo altlarındaki açıklayıcı bilgilerle detaylı bir şekilde anlatılmaktadır. 
Tablo 1. Sosyal Görünüş Kaygısı Ve Öznel Mutluluk Ölçeği Puanları Dağıımı

\begin{tabular}{llllllll}
\hline & Madde & N & Ort. \pm Ss & Çarpıkık & Basıklık & Min. & Maks. \\
& Sayısı & & & & & & \\
\hline SGKÖ & 16 & 238 & $1.81 \pm 0.63$ & 1.09 & 0.82 & 16.00 & 61.00 \\
ÖMÖ & 4 & 238 & $4.92 \pm 0.98$ & -0.16 & -0.31 & 10.00 & 28.00 \\
\hline
\end{tabular}

Tablo 1'e göre; araştırmaya konu olan katılımcıların SGKÖ puanlarının aritmetik ortalaması 1.81 ve standart sapması 0.63; mutluluk puanlarının aritmetik ortalaması 4.92 ve standart sapması 0.98'dir. Kline (2005), Çarpıklık değerinin \pm 3 ve Basıklık değerinin de \pm 10 sınırları içerisinde olmasının, verilerin normal dağılımının bir göstergesi olarak değerlendirilebileceğini belirtmektedir.

Tablo 2. Cinsiyete Göre T-Testi Sonuçları

\begin{tabular}{lllll}
\hline & $\begin{array}{l}\text { Kadın }(n=146) \\
\text { Ort. } \pm \text { Ss }\end{array}$ & $\begin{array}{l}\text { Erkek }(n=92) \\
\text { Ort. } \pm \text { Ss }\end{array}$ & $\mathrm{t}$ & $\mathrm{p}$ \\
\hline SGKÖ & $1.86 \pm 0,65$ & $1.73 \pm 0.59$ & 1.52 & 0.12 \\
ÖMÖ & $4.88 \pm 0,98$ & $5.00 \pm 0.97$ & -0.89 & 0.37 \\
\hline p>0.05 & & & &
\end{tabular}

Katılımcıların sosyal görünüş kaygısı ve mutluluk puanlarının; cinsiyete göre anlamlı bir farklılık gösterip göstermediğini belirlemek amacıyla yapılan t-testi sonuçları Tablo 2'de sunulmuştur. Tablo 2'ye göre spor hizmeti alan bireylerin sosyal görünüş kaygısı puanları ( $t=1.52 ; \mathrm{P}>0.05)$ ve mutluluk puanları $(\mathrm{t}=-0.89$; $\mathrm{P}>0.05)$ cinsiyet değişkenine göre anlamlı bir farklılık göstermemektedir.

Tablo 3. Yaşa Göre ANOVA Sonuçları

\begin{tabular}{|c|c|c|c|c|c|}
\hline & $\begin{array}{l}15-20 \text { yaş } \\
(n=40)\end{array}$ & $\begin{array}{l}21-26 \text { yaş } \\
(n=130)\end{array}$ & $\begin{array}{l}27 \text { ve üzeri yaş } \\
(n=68)\end{array}$ & $\mathrm{F}$ & $p$ \\
\hline & Ort. \pm Ss & Ort. \pm Ss & Ort. \pm Ss & & \\
\hline SGKÖ & $2.01 \pm 0.73$ & $1.78 \pm 0.56$ & $1.74 \pm 0.67$ & 2.47 & 0.08 \\
\hline ÖMÖ & $4.73 \pm 1.05$ & $4.87 \pm 1.01$ & $5.15 \pm 0.82$ & 2.87 & 0.06 \\
\hline
\end{tabular}

Tablo 3 katılımcıların sosyal görünüş kaygısı ve mutluluk puanlarının; yaşa göre anlamlı bir farklılık gösterip göstermediğini belirlemek amacıyla yapılan ANOVA sonuçlarını göstermektedir. Tablo 3'e göre; spor hizmeti alan bireylerin sosyal 
görünüş kaygıları ve mutlulukları, yaş değişkenine göre istatistiksel açıdan anlamlı bir farklılık göstermemektedir (FSGK=2.47; FM=2.87; $\mathrm{P}=0.08 / 0.06>0.05$ ).

Tablo 4. Medeni Duruma Göre T-Testi Sonuçları

\begin{tabular}{lllll}
\hline & $\begin{array}{l}\text { Bekâr }(n=80) \\
\text { Ort. } \pm \text { Ss }\end{array}$ & $\begin{array}{l}\text { Evli }(n=158) \\
\text { Ort. } \pm \text { Ss }\end{array}$ & $\mathrm{t}$ & $\mathrm{p}$ \\
\hline SGKÖ & $1.75 \pm 0.55$ & $1.84 \pm 0.67$ & -1.04 & 0.29 \\
ÖMÖ & $4.99 \pm 0.93$ & $4.89 \pm 0.50$ & 0.69 & 0.48 \\
\hline
\end{tabular}

$p>0.05$

Katılımcıların sosyal görünüş kaygısı ve mutluluk puanlarının; medeni duruma göre anlamlı bir farklılık gösterip göstermediğini belirlemek amacıyla yapılan t-testi sonuçları Tablo 4'te sunulmuştur. Tablo 4'e göre spor hizmeti alan bireylerin sosyal görünüş kaygısı puanları ( $\mathrm{t}=-1.04 ; \mathrm{P}>0.05)$ ve mutluluk puanları $(\mathrm{t}=0.69 ; \mathrm{P}>0.05)$ medeni durumu değişkenine göre anlamlı bir farklılık göstermemektedir.

Tablo 5. Gelir Durumuna Göre ANOVA Sonuçları

\begin{tabular}{|c|c|c|c|c|c|c|}
\hline & $\begin{array}{l}\text { Düşük } \\
(n=36)\end{array}$ & $\begin{array}{l}\text { Orta } \\
(n=183)\end{array}$ & $\begin{array}{l}\text { Yüksek } \\
(n=19)\end{array}$ & $\mathrm{F}$ & $P$ & Anlamlı Fark \\
\hline & Ort. \pm Ss & Ort. \pm Ss & Ort. \pm Ss & & & \\
\hline SGKÖ & $1.82 \pm 0.62$ & $1.81 \pm 0.63$ & $1.68 \pm 0.68$ & 0.41 & 0.66 & \\
\hline ÖMÖ* & $4.34 \pm 0.32$ & $\begin{array}{l}5.01 \\
0.95\end{array}$ & $5.22 \pm 0.96$ & 8.31 & 0.00 & Düşük-Orta-Yüksek \\
\hline
\end{tabular}

${ }^{*} \mathrm{p}<0.05$

Tablo 5 katılımcıların sosyal görünüş kaygısı ve mutluluk puanlarının; gelir durumuna göre anlamlı bir farklılık gösterip göstermediğini belirlemek amacıyla yapılan ANOVA sonuçlarını göstermektedir. Tablo 5'e göre; spor hizmeti alan bireylerin sosyal görünüş kaygıları, gelir değişkenine göre istatistiksel açıdan anlamlı bir farklılık göstermemektedir (FSGK=0.41; $\mathrm{P}>0.05)$. Bireylerin mutluluk puanları ise, gelir değişkenine göre anlamlı bir farklılık göstermektedir (FÖM=8.31; $P<0.05)$. Diğer bir ifade ile katılımcıların mutlulukları gelir durumuna bağlı olarak anlamlı bir şekilde değişmektedir. Gelir durumu grupları arasındaki farklılaşmanın hangi gruplar arasında olduğunu tespit etmek amacıyla yapılan Tukey HSD testinin sonucuna göre, yüksek gelir düzeyine sahip olan bireylerin $(\bar{x}=5.22)$ ve orta gelir düzeyine sahip olan bireylerin mutluluk puan ortalaması $(\bar{x}=5.01)$ düşük gelir düzeyine sahip olan bireylerin mutluluk puan ortalamasına $(\bar{x}=4.34)$ göre istatistiksel olarak daha yüksektir. 
Tablo 6. Mutluluk İle Sosyal Görünüş Kaygısı Arasındaki Korelasyon Sonuçları

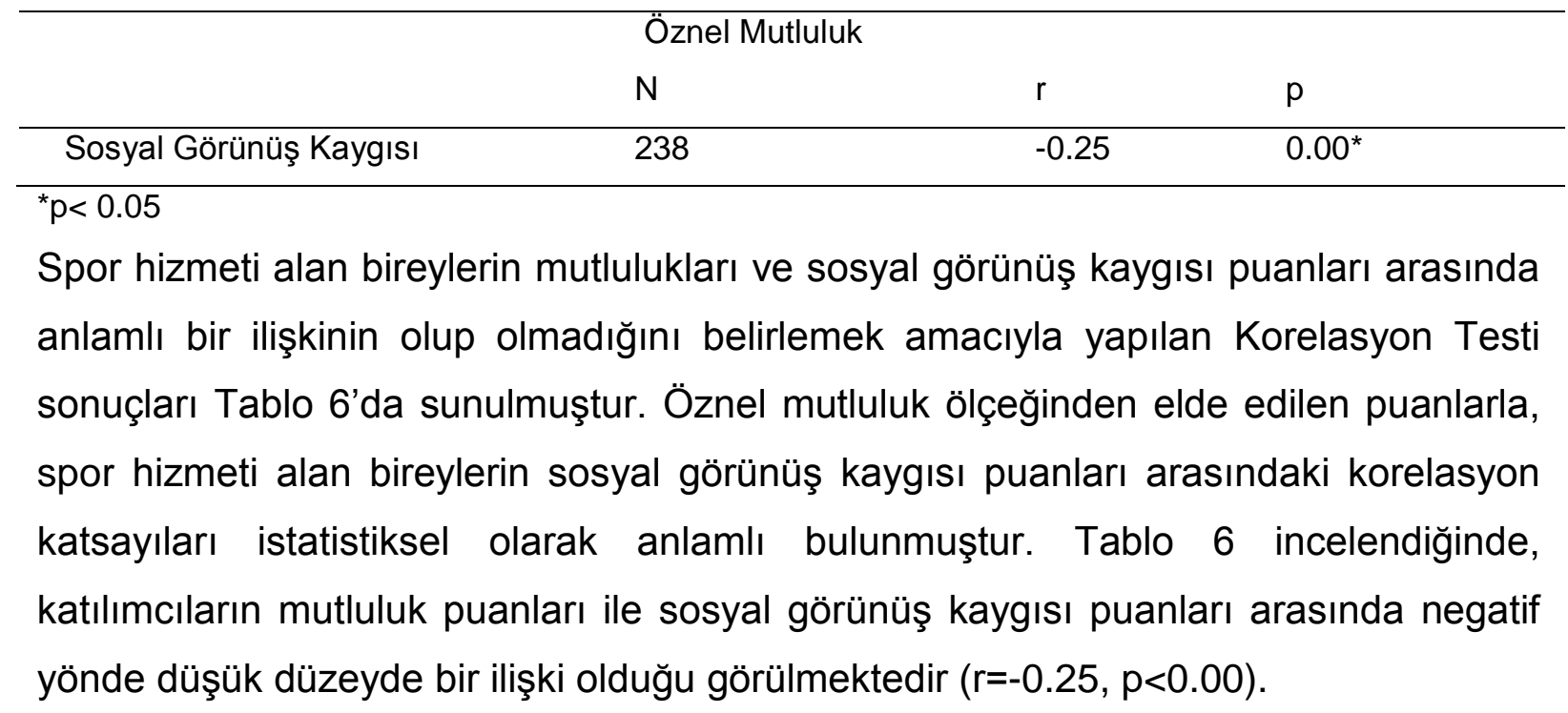

\section{Tartışma}

Katılımcılardan toplanan veriler değerlendirilmiş ve SGK ile ÖM puanlarının normallik varsayımını sağlayıp sağlamadığı irdelenmiş ve verilerin normal dağılım gösterdiği tespit edilmiştir. Yazıcı, Caz ve Tunçkol (2016) tarafından yapılan çalışmanın sosyal görünüş kaygısı ölçek puan dağılımına bakıldığında verilerin normal dağıım gösterdiği belirlenmiştir. Yalız Solmaz (2014)'ın öğretmen adayları üzerinde yapmış olduğu çalışmanın öznel iyi oluş ölçeğinin verilerinin normal dağılım gösterdiği görülmüştür. Yazıcı ve ark., (2016)'nin Spor Genel Müdürlüğü taşra teşkilatında görevli personele yaptıkları çalışmanın mutluluk ölçeği puan dağılımına bakıldığında da verilerin normallik varsayımını sağladığı tespit edilmiştir. Ancak Telli ve Ünal (2016) tarafından üniversite öğrencileri üzerinde yapılan sosyal görünüş kaygısını irdeledikleri çalışmanın verilerinin normal dağılım göstermediği belirlenmiştir.

Cinsiyet değişkeni açısından bireylerin sosyal görünüş kaygısı ve mutluluk puanları anlamlı bir farklılık göstermemektedir. Bu bulgu, kadın ve erkek bireylerin cinsiyet bazında kaygı taşımadıklarını göstermektedir. Çepikkurt ve Coşkun (2010)'un üniversiteli dansçılar; Varol ve ark., (2014)'nin ergenler; Telli ve Ünal (2016)'ın üniversite öğrencileri; Koparan ve ark., (2010)'nin ise beden eğitimi öğretmenleri üzerinde yapmış oldukları çalışmaların cinsiyet değişkeninde sosyal görünüş kaygısı açısından kadın ve erkekler arasında manidar bir farklılık tespit edememeleri, mevcut çalışmanın cinsiyet değişkeni sonucunu desteklemektedirler. 
Ancak, Kuru ve Baştuğ (2008)'un futbolcular; Bilbek ve Yılmaz (2014)'ın öğrenciler; Yaşartürk ve ark., (2014)'nin öğrenciler; Alemdağ ve Öncü (2015)'nün öğretmen adayları üzerinde gerçekleştirmiş oldukları çalışmaların cinsiyet değişkenlerinde kadın ve erkekler arasında sosyal görünüş kaygısı açısından istatistiki açıdan farklılık tespit edilmesi, çalışmanın cinsiyet sonucu ile örtüşmemektedir. Mevcut çalışmanın mutluluk bağımlı değişkeninde kadın ve erkek bireyler arasında manidar bir farklılık tespit edilmemiştir. Saygın ve Arslan (2009)'ın üniversite öğrencileri; Certel ve ark., (2015)'nin lise öğrencileri; Canbay (2010)'ın lise öğrencileri; Solmaz (2014)'ın öğretmen adayları üzerinde yapmış oldukları çalışmaların cinsiyet açısından mutluluk düzeyinde kadın ve erkeler arsında anlamlı farklılık tespit edilememesi, çalışmanın cinsiyet değişkeni sonucunu desteklemektedir.

Bireylerin sosyal görünüş kaygıları ve mutluluk düzeyleri, yaş değişkenine göre istatistiksel açıdan anlamlı bir farklılık göstermemiştir. Bu noktada, yaşın mutluluk ve görünüş kaygısı üzerinde etkili olmadığı anlaşılmaktadır. Koparan ve ark., (2010) tarafından beden eğitimi öğretmenleri; Korkmaz ve ark., (2003) tarafından ise Beden Eğitimi ve Spor Bölümü öğrencileri üzerinde yapılan çalışmaların yaş değişkeninde anlamlı farklılık tespit edilememesi sosyal görünüş kaygısı noktasında mevcut çalışmanın yaş değişkeni sonucu ile benzerlik göstermektedir. Fakat Telli ve Ünal (2016) tarafından üniversite öğrencilerinin konu edindiği çalışmada farkı yaş grupları arasından manidar farklıık tespit edilmesi, çalışmanın yaş değişkeni sonucunu destekler niteliktedir. Ancak, öznel iyi oluş noktasında Erginsoy ve Kaya (2013) tarafından öğretmen adaylarına yapılan çalışmanın yaş değişkeninde anlamlı farklılık tespit edilmesi, çalışmanın sonucu ile çelişmektedir.

Öznel mutluluk ile sosyal görünüş kaygısı puanları arasındaki ilişkiyi saptamak için gerçekleştirilen korelasyon testi sonucu, bireylerin mutluluk ile sosyal görünüş kaygısı puanları arasında negatif yönde düşük düzeyde bir ilişki olduğu görülmektedir. Bu bulgu, bireylerin görünüş kaygıları azaldıkça mutluluk düzeylerinin arttığını göstermektedir. Benzer şekilde, Oktan (2012) tarafından yapılan çalışmada da öznel iyi oluş ile beden imajı arasında negatif yönde anlamlı düşük düzeyde ilişki bulunmuştur. 


\section{Sonuç ve Öneriler}

Katılımcılardan toplanan veriler değerlendirilmiş ve SGK ile ÖM puanlarının normallik varsayımını sağlayıp sağlamadığı irdelenmiş ve verilerin normal dağılım gösterdiği tespit edilmiştir. Cinsiyet değişkeni açısından bireylerin sosyal görünüş kaygısı ve mutluluk puanları anlamlı bir farklılık göstermemektedir. Bu bulgu, kadın ve erkek bireylerin cinsiyet bazında kaygı taşımadıklarını göstermektedir. Bireylerin sosyal görünüş kaygıları ve mutluluk düzeyleri, yaş değişkenine göre istatistiksel açıdan anlamlı bir farklılık göstermemiştir. Bu noktada, yaşın mutluluk ve görünüş kaygısı üzerinde etkili olmadığı anlaşılmaktadır.

Sosyal görünüş kaygısı ile mutluluk puanları medeni durumu değişkeni açısından da istatistiksel açıdan manidar bir farklılık göstermemektedir. Bireylerin sosyal görünüş kaygıları, gelir değişkenine göre istatistiksel açıdan anlamlı bir farklılık göstermez iken, mutluluk puanları gelir değişkenine göre anlamlı bir farklılık göstermektedir. Bu bulgu, bireylerin gelir durumunun görünüş kaygısı üzerinde etkili olmadığını gösterirken, gelir durumunun mutluluk düzeyi üzerinde etkili olduğunu göstermektedir. Öznel mutluluk ile sosyal görünüş kaygısı puanları arasındaki ilişkiyi saptamak için gerçekleştirilen korelasyon testi sonucu, bireylerin mutluluk ile sosyal görünüş kaygısı puanları arasında negatif yönde düşük düzeyde bir ilişki olduğu görülmektedir. Bu bulgu, bireylerin görünüş kaygıları azaldıkça mutluluk düzeylerinin arttığını göstermektedir.

Gerçekleştirilecek çalışmalarda, farklı il ve bölgede yer alan bireylerinde çalışmaya dâhil edilebilir. Yapılacak çalışmalarda bağımsız değişken sayısı arttırılabilir. Ayrıca yapılacak çalışmalarda karma yöntem kullanılabilir.

\section{Kaynaklar}

Akın, A., \& Satıcı, S.A. (2011). Öznel mutluluk ölçeği: Geçerlik ve güvenirlik çalışması. Sakarya Üniversitesi Eğitim Fakültesi Dergisi, 21, 65-77.

Alemdağ, S., \& Öncü, E. (2015). Öğretmen adaylarının fiziksel aktiviteye katıım ve sosyal görünüş kaygılarının incelenmesi. International Journal of Science Culture and Sport, Special Issue, 3, 287-300.

Baysal, S., \& Aka, Ç.I. (2013). Bir pazarlama stratejisi olarak mutluluk temasının markalar tarafından kullanıması: Mutluluk temelli pazarlama üzerine bir araştırma. Sosyal ve Beşeri Bilimler Dergisi, 5(1), 84-93. 
Bilbek, M., \& Yılmaz, C.Y. (2014). Beden eğitimi ve spor yüksekokulu öğrencilerinin sosyal karşılaştırma düzeylerinin çeşitli değişkenler açısından incelenmesi. Ankara Üniversitesi Spor Bilimleri Fakültesi Spormetre Dergisi, 12(2), 105-112.

Canbay, H. (2010). Lise Öğrencilerinin Öznel İyi Oluş Düzeyleri ile Sosyal Beceri Düzeyleri Arasındaki Iliş̧inin İncelenmesi. Dokuz Eylül Üniversitesi, Yüksek Lisans Tezi, İzmir.

Cash,T.F., \& Fleming E.C. (2002). The impact of body image experiences: Development of the body image quality of life inventory. Journal of Eating Disorder, 31, 455-460.

Certel, Z., Bahadır, Z, Saracaloğlu, A.S., \& Varol, R. (2015). Lise öğrencilerinin özyeterlikleri ile öznel iyi oluş düzeyleri arasındaki ilişkinin incelenmesi. Eğitim ve Öğretim Araştırmaları Dergisi, 4(2), 307-318.

Costa, P.T., \& Mccrae R.R. (1980). Influence of extraversion and neuroticism on subjective well-being: Happy and unhappy people. Journal of Personality and Social Psychology, 38, 668-678.

Çepikkurt, F., \& Çoşkun F. (2010). Üniversiteli dansçıların sosyal fizik kaygı ve beden imgesinden hoşnut olma düzeyleri. Pamukkale Spor Bilimleri Dergisi, 1(2), 1724.

Çınar, H., \& Keskin, N. (2015). Öğrencilerin sosyal görünüş kaygısının öğrenim yeri tercihlerine etkisi. Electronic Journal of Vocational Colleges, 14, 457-464.

Deci, E., \& Ryan, R. (2000). The "what" and "why" of goal pursuits: Human needs and the self-determination of behaviour. Psychological Inquiry, 11(4), 227-269.

Deci, E., Ryan, R., Gagne, M., Lronr, D., Usunov, J., \& Kornazheva, B. (2001). Need satisfaction, motivation and well-being in the work organizasions of a former esatern bloc country: A cross-cultural study of self determination. Personality and Social Psychology Bulletin, 27(8), 930-942.

Diener, E., Wolsic, B., \& Fujita F. (1995). Physical attractiveness and subjective wellbeing. Journal of Personality and Social Psychology, 69, 120-129.

Doğan, T. (2010). Sosyal görünüş kaygısı ölçeğinin Türkçe uyarlaması: Geçerlilik ve güvenirlik çalışması. Hacettepe Üniversitesi Eğitim Fakültesi Dergisi, 39, 151159.

Donaghue, N. (2009). Body satisfaction, sexual self-schemas and subjective wellbeing in women. Body Image, 6, 37-42. 
Durkin, S.J., \& Paxton S.J. (2002). Predictors of vulnerability to reduced body image satisfaction and psychological wellbeing in response to exposure to, idealized female media images in adolescent girls. Journal of Psychosomatic Research, 53, 995-1005.

Elliot, A., Sheldon, K., \& Church M. (1997). Avoidance personal goals and subjective well-being. Personality and Social Psychology, 23(9), 915-927.

Emmons, R.A. (1986). Personal strivings: An approach to personality and subjective well-being. Journal of Personality and Social Psychology, 51, 1058-1068.

Erginsoy, O.D., \& Kaya, H.İ. (2013). Öğretmen adaylarının yükseköğretime dair memnuniyet durumları ile öznel iyi oluş durumlarının değerlendirilmesi: Kafkas Üniversitesi örneği. Journal of the Institute of Social Sciences, 12, 45-70.

Gautreau, M.C., Simon, B, Mushquash, R.A., \& Sherry S.H. (2015). Is self-critical perfectionism an antecedent of or a consequence of social anxiety, or both? $\mathrm{A}$ 12-month, three wave longitudinal study. Personality and Individual Differences, 82, 125-130.

Hart, T.A., Flora, D.B., Palyo, S.A, Fresco, D.M, Holle, C., \& Heimberg, R.C. (2008). Development and examination of the social appearance anxiety scale. Assessment, 15, 48-59.

Headey, B., \& Wearing, A. (1989). Personality, life events, and subjective wellbeing: Toward a dynamic equilibrium model. Journal of Personality and Social Psychology, 57, 731-739.

Kalemoğlu, V.Y., Erbaş, M.K., \& Ünlü, H. (2014). The relationship between social appearance anxiety of adolescents and their attitude toward physical education lesson. Nigde University Journal of Physical Education And Sport Sciences, 8(1), 121-130.

Kara, A. (2016). Sosyal görünüş kaygısı ile utangaçlık arasındaki ilişkilerin incelenmesi. Birey ve Toplum Dergisi, 6(11), 95-106.

Kasser, T., \& Ryan, R. (1999). The relations of psychological needs for autonomy and relatedness to vitality, well- being and mortality in a nursing home. Journal of Applied Social Psychology, 29(5), 935-954.

Katz, J., \& Farrow, S. (2000). Discrepant self-views and young women's sexual and emotional adjustment. Sex Roles, 42, 781-805. 
Koparan, Ş., Öztürk, F., \& Korkmaz N.H. (2010). Beden eğitimi öğretmenlerinin özyeterlik algısı ve sosyal fizik kaygı düzeylerinin bazı değişkenler açısından incelenmesi (Bursa örneği). E-journal of new World sciences Academy, 5(4), 286-293.

Korkmaz, N.H, Şahin, E., Kahraman, M., \& Öztürk F. (2003). U.Ü. Eğitim Fakültesi Beden Eğitimi ve Spor Bölümü öğrencilerinin empatik becerilerinin yaşa göre karşılaştırıması. Uludağ Üniversitesi Eğitim Fakültesi Dergisi, 17(1), 95-103.

Kuru, E., \& Baştuğ, G. (2008). Futbolcuların kişilik özellikleri ve bedenlerini algılama düzeylerinin incelenmesi. Ankara Üniversitesi Spor Bilimleri Fakültesi Spormetre Dergisi, 6(2), 95-101.

Kline, R. B. (2005). Principles and Practice of Structural Equation Modeling: Methodology In The Social Sciences. New York, NY: Guilford Press.

Leary. M.R., \& Kowalski R.M. (1995). Social Anxiety. New York: Guilford.

Lyubomirsky, S., King, L., \& Diener, E. (2005). The benefits of frequent positive affect: Does happiness lead to success? Psychological Bulletin, 131(6), 803855.

Michalos, A.C. (1985). Multiple discrepancy theory (MDT). Social Indicators Research, 16, 347-413.

Oktan, V. (2012). Beden imajı ve reddedilme duyarlıı̆ının öznel iyi oluşu yordama gücü. Eğitim Bilimleri ve Uygulama, 11(22), 119-134.

Omodei, M.M., \& Wearing, A.J. (1990). Need satisfaction and involvement in personal projects: Toward an integrative model of subjective well-being. Journal of Personality and Social Psychology, 59, 762-769.

Saygın, Y., \& Arslan, C. (2009). Üniversite öğrencilerinin sosyal destek, benlik saygısı ve öznel iyi oluş düzeylerinin incelenmesi. Selçuk Üniversitesi Ahmet Keleşoğlu Eğitim Fakültesi Dergisi, 28, 207 -222.

Telli, E., \& Ünal, Z. (2016). Üniversite öğrencilerinin sosyo-demografik özelliklerine göre sosyal görünüş kaygısı: Bir alan araştırması. Mehmet Akif Üniversitesi Sosyal Bilimler Enstitüsü Dergisi, 8(15), 134-146.

Tiggeman, M. (1994). Gender differences in the interrelationships between weight dissatisfaction, restraint, and self esteem. Sex Roles, 30, 319-330.

Tuzgöl,D.M. (2006). Subjective well-being among university students. Hacettepe Üniversitesi Eğitim Fakültesi Dergisi, 31, 188-197. 
Yalnız, S.D. (2014). Öğretmen adaylarının öznel iyi oluş düzeyleri: Anadolu Üniversitesi Beden Eğitimi ve Spor Öğretmenliği Bölümünde bir araştırma. Uluslararası Sosyal Araştırmalar Dergisi, 7(35), 651-657.

Yaman, C., Koşu, S., Tel, M., Teşneli, Ö., Yalvaracı, N., \& Gelen, N. (2008). Elit seviyedeki değişik spor branşlarının fiziksel benlik algısı üzerine etkisi. Uluslararası İnsan Bilimleri Dergisi, 5(2), 1-17.

Yaşartürk, F., Çalık, F., Kul, M., Türkmen, M., \& Akyüz, H. (2014). Beden Eğitimi ve Spor Yüksekokulunda okuyan öğrencilerin sosyal fiziki kaygı durumlarının incelenmesi. International Journal of Science Culture and Sport, Special Issue 1, 863-869.

Yazıcı, Ö.F., Caz, Ç., \& Tunçkol, H.M. (2016a). Gençlik Hizmetleri ve Spor III Müdürlüğü'nde görev yapan personelin sosyal görünüş kaygısı. Uluslararası Spor, Egzersiz ve Antrenman Bilimi Dergisi, 2(2), 60-65.

Yazıcı, Ö.F, Caz Ç, \& Tunçkol H.M. (2016b). Spor Genel Müdürlüğü taşra teşkilatında çalışan personelin öznel mutluluk düzeyleri. Uluslararası Spor, Egzersiz ve Antrenman Bilimi Dergisi, 2(1), 125-131.

Yousefi, B., Hassani, Z., \& Shokri, O. (2009). Reliability and factor validity of the 7item social physique anxiety scale (SPAS-7) among university students in Iran. World Journal of Sport Sciences, 2(3), 201-204. 